\title{
СПРИНКЛЕР ИНСТАЛАЦИЈА ЗА ГАШЕЊЕ ПОЖАРА У СТАМБЕНОМ ОБЈЕКТУ - ГАРАЖА
}

\section{SPRINKLER INSTALLATION FOR EXTINGUISHING FIRE IN THE BUILDING - GARAGE}

\author{
Ненад Драгин, Факултет техничких наука, Нови Сад
}

\section{Област - УПРАВЉАЊЕ РИЗИКОМ ОД КАТАСТРОФАЛНИХ ДОГАЪАЈА И ПОЖАРА}

Кратак садржај - У раду је приказан пројекат аутоматске спринклер инсталаиије за гашење пожара водом за подземну гаражу стамбеног објекта. Детаљно је описан принции рада инсталачије као и њене предности приликом уградње. У раду се водило следећим битним чињеницама приликом одабира аутоматског стабилног система за гашење пожара: битно узети у обзир намену предметног објекта као $u$ класу пожарне опасности, ватроотпорност грађевинских елемената, уређаје за гашење пожара, сигурне методе рада и добру организацију.

Кључне речи: Аутоматска спринклер инсталација, заштита од пожара, пројекат спринклер инсталације гараже стамбеног објекта

Abstract: The paper presents the project of an automatic sprinkler installation for extinguishing fire with water for the underground garage of a residential building. The principle of operation of the installation and its advantages during installation are described in detail. The paper was guided by the following important facts when choosing an automatic stable fire extinguishing system: it is important to take into account the purpose of the object as well as the fire hazard class, fire resistance of building elements, fire extinguishers, safe working methods and good organization.

Keywords: Automatic sprinkler installation, Fire safety, Project of Sprinkler installation of a resindential garage

\section{1. УВОД}

Предмет разматрања овог рада су пожари, процена висине пожарног ризика, аутоматска спринклер инсталација за гашење пожара као и њена примена у подземној гаражи стамбеног објекта, која због свог положаја, специфичног пожарног оптерећења, вентилације и других фактора представља изазов за све оне који се баве заштитом од пожара.

У раду је приказан пројекат спринклер инсталације за подземну гаражу усклађен законом о заштити од пожара, а прорачун и димензионисање инсталације извршене према стандардима ВдС ЦЕА 4001 и СРПС EH 12845.

\section{НАПОМЕНА:}

Овај рад проистекао је из мастер рада чији је ментор др Митар Јоцановић, ванр.проф.
Спринкелер систем је најраспрострањенији стабилни аутоматски уређај за дојаву и гашење пожара.

Овај систем најчешћу примену проналази у робним кућама, хотелима, болницама, у складиштима, индустријским објектима, подземним гаражама итд. Приликом одабира спринклер инсталације неопходно је узети у обзир и размотрити низ фактора и критеријума.

Извођење ових инсталација може се категоризовати на:

- мокре спринклер инсталације,

- суве спринклер инсталације,

- комбиноване спринклер инсталације,

- суве брзодејствујуће спринклер инсталације,

- суве спринклер инсталације са претходним

управљањем.

Уградњом спринклер система, спречава се брзо ширење пожара, као и настала материјална штета. Многа осигуравајућа друштва умањују премију осигурања клијентима који имају уграђене спринклер системе, што доноси значајну уштеду у трошковима осигурања.

Многе осигуравајуће компаније чак одбијају и да издају било какву полису осигурања у објектима где је велик ризик од избијања пожара, а при томе немају спринклер инсталацију.

Циљ овог рада је приказ ефикасности уградње спринклер система у гаражним објектима.

\section{2. ПОЖАРИ}

\section{1. Класе пожара}

Према СРПС З.ЦО.003 пожари се разврставају у пет класа према врсти горивих материја које могу бити обухваћене пожаром:

- Класа A - пожари чврстих запаљивих материја (пожари са стварањем жара - дрво, папир, слама, текстил, угаљ и слично)

- Класа Б - пожари запаљивих течности (бензин, уља, лакови, смоле, катран)

- Класа Ц - пожари запаљивих гасова (градски гас, ацетилен, метан, пропан, бутан и слично)

- Класа Д - пожари запаљивих метала (алуминијум, магнезијум, натријум, калијум и друго)

- Класа $E$ - пожари на уређајима и инсталацијама под електричним напоном (електромотори, трансформатори, разводна постројења и друго).

Према месту где се пожар развија и условима размене топлоте и масе гасовите фракције са околином, 
пожари се могу разврстати на спољашње и унутрашње, а према њиховом обиму и величини на мале, средње, велике и блоковске пожаре. Пратећи продукти пожара су топлота и продукти сагоревања без обзира на материју која гори и постојећих услова за размену масе гасовитих фракција. Када се говори о продуктима сагоревања, обично се мисли на гасовите, течне (капи и паре) и чврсте материје, мада се при томе не би требала занемарити ослобођена енергија. Од пратећих појава у пожару најзначајнија је ослобођена хемијска енергија у виду топлоте. Она у највећој мери зависи од топлотне моћи материје али и од других учесника у хемијској реакцији.

\section{2. Могући узроци пожара}

За што успешнију борбу против пожара потребно је елиминисати њихове узроке. Елиминисање узрока пожара подразумева знање о њиховом настајању, тј. како и где се јављају. Одговоре на ова питања дају анализе пожара, па се на основу статистичких података о узроцима пожара врше стручне обраде ради предузимања потребних превентивних мера. Обзиром на огроман број могућих узрока пожара, обично се дају основне класификације и типични случајеви који обухватају највећи број узрока пожара. Као и сви статистички подаци и подаци о узроцима пожара зависе од методологије, броја пожара, периода времена, степена индустријализације итд. При анализи таквих података може се извршити основно груписање узрока пожара:

- техничке неисправности - кварови,

- технички недостаци - непоштовање техничких прописа, лош квалитет и др,

- људски фактор - непажња, нестручност, нехат, дечија игра, намерно паљење,

- организациони недостаци - одсуство контроле, организације пожарне службе, непоштовање закона,

- природни узрочници - гром, земљотрес, сунце.

Код подземних гаража аутомобили су најчешћи узрозници пожара. Америчка агенција НФПА наводи да су електрични и механички кварови узроковали $2 / 3$ пожара на аутомобилима. Аутомобили садрже пуно запаљивих и горивих материја и материјала као што је погонско гориво, моторно уље, пластика, седишта, гуме и остали материјали који се могу наћи у аутомобилима.

Најчешћи узроци пожара на аутомобилима су неисправност електричних инстлација, неисправност батерија код електричних возила, прегрејавање мотора, цурење резероара итд. Евентуални пожари у подземним гаражама се веома лако шире, а постоји опасност и од евентуалних експлозија.

\section{3. ПРОЦЕНА ВИСИНЕ ПОЖАРНОГ РИЗИКА}

Процена пожарног ризика представља основу за доношење одлуке о уградњи аутоматског стабилног система за гашење, као допунске мере заштите. Оправданост постављања аутоматске инсталације за гашење пожара одређује се на основу величине пожарног ризика за конструкцију објекта (носећи елементи, међуспратне конструкције, кровне конструкције и сл.), као и на основу пожарног ризика за садржај објекта (људи, опрема, намештај, ускладиштена роба и сл.)

\section{1. Пожарни ризик објекта}

Пожарни ризик за објекат зависи од могућег интезитета и одвијања пожара, као и конструктивних карактеристика носивих елемената објекта (отпорност конструкције према деловању високих температура), а израчунава се према обрасцу:[24]

$$
R_{O}=\frac{\left[\left(P_{O} \cdot C\right)+P_{k}\right] \cdot B \cdot L \cdot S}{W \cdot R_{i}}
$$

\section{2. Пожарни ризик садржаја објекта}

Пожарни ризик за садржај објекта (опасност за људе, намештај, опрему, складиштену робу и слично) израчунава се на основу обрасца.

$$
\mathrm{R}_{\mathrm{s}}=\mathrm{H} \cdot \mathrm{D} \cdot \mathrm{F}
$$

За добијене вредности пожарног ризика за објекат $\mathrm{R}_{0}$, као и пожарног ризика садржаја објекта $R_{s}$, помоћу приложеног дијаграма и познате апцисе (пожарни ризик садржаја објекта) и ординате (пожарни ризик за објекат) одређује се прорачунска тачка слика 1. Кад прорачунска тачка падне у шрафирани део приложеног дијаграма, оправдано је у тим околностима поставити аутоматски стабилни систем за гашење пожара на основу висине пожарног ризика објекта

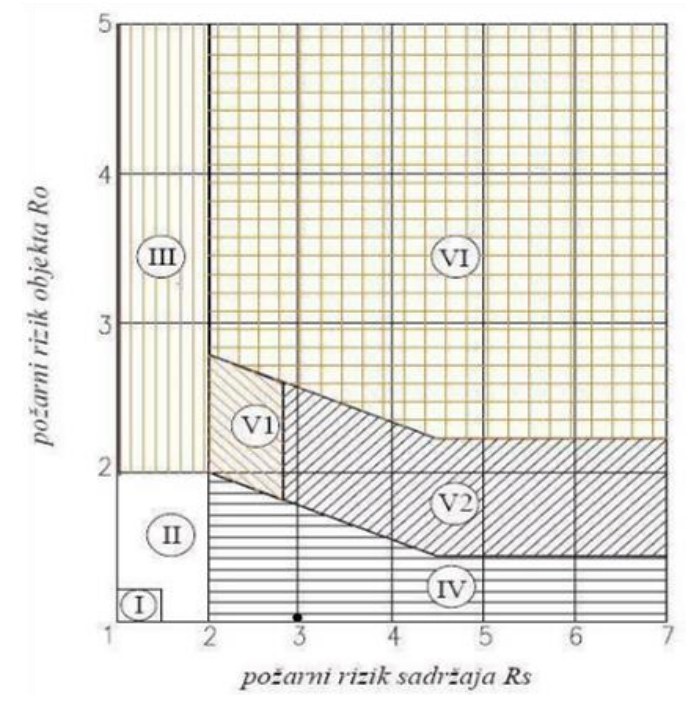

Слика 1. Дијаграм пожарног ризика

\section{4. АУТОМАТСКЕ ИНСТАЛАЦИЈЕ ЗА ГАШЕЊЕ ПОЖАРА ВОДОМ-СПРИНКЛЕР ИНСТАЛАЦИЈА}

Спринклер инсталација спада међу најефикасније инсталације за гашење пожара. То је аутоматска инсталација са распрскавајућим млазом воде, која у припремном положају и пре активирања има затворене млазнице, које се отварају на одређеној, пројектованој температури и на тај начин започиње аутоматско активирање инсталације.

Цевоводи који доводе воду до млазница су под сталним притиском воде или ваздуха, у зависности од инсталације. 
Гашење пожара се врши одређеним бројем млазница, зависно од брзине ширења пожара.

Приликом појаве пројектоване температуре, долази до пуцања ампуле на млазници услед ширења експанзионе течности која се налази у ампули. Експанзиона течност врши притисак на зидове ампуле и на тај начин долази до пуцања ампуле при чему се отвара излаз води.

Вода удара у дефлектор и распршава се тако да у кружној лепези покрива површину која се штити. У случају да првоактивирана млазница не успе да угаси пожар, па се он прошири, отварају се следеће млазнице у непосредној близини места пожара.

Услед отварања млазнице и пада притиска у цевоводу иза спринклер вентила, подиже се клапна у спринклер вентилу и вода потиче ка спринклер млазницама. Преко жљеба у седишту спринклкер вентила вода улази у цевовод према хидрауличном алармном звону где се добија механички сигнал о проради спринклер инсталације.

Поред гашења, при активирању спринклер инсталације и при кретању воде кроз цевоводе, преостат спринклер вентила и индикатор протока у цевоводима дају сигнал да је инсталација прорадила.

\section{5. ТЕХНИЧКИ ИЗВЕШТАЈИ И ПРОРАЧУНСКЕ OCHOBE}

Предметни објекат је спратности По+Пр+3+Пк. У сутерену објекта је смештена подземна гаража за паркирање аутомобила која припадају станарима зграде у улици Лазе Лазаревића. Гаражи се приступа из дворишта објекта, и садржи 42 паркинг места као и бициклану. Поред паркинг места са комуникацијама у простору подземне гараже се налазе и помоћне просторије као и спринклер пумпна станица са пратећом опремом. Из подземне гараже се степеницама и лифтом може директно ићи на више етаже.

Подземна гаража која се налази у предметном објекту према члану 14 Правилника о техничкм захтевима за заштиту гаража за путничке аутомобиле од пожара („Сл. лист СЦГ“, бр. 31/2005) спада у „СРЕДњУ“ гаражу, укупне бруто површине $1444 \mathrm{~m}^{2}$.

У предметном објекту су изведени следећи системи и опрема:

- стабилни систем за аутоматско гашење пожара спринклер

• ручни преносни апарати за гашење пожара

- хидрантска мрежа

- стабилни систем за аутоматску дојаву пожара и детекцију експлозивних гасова и пара

\section{6. ГЛАВНИ ПРОЈЕКАТ СПРИНКЛЕР ИНСТАЛАЦИЈЕ ЗА ПОДЗЕМНУ ГАРАЖУ СТАМБЕНОГ ОБЈЕКТА СУ+Пр+3+ПК}

Прорачун спринклер инсталације може се вршити у складу са једним од неколико постојећих стандарда: ЕН 12845 (стандард које су усвојиле земље ЕУ), ВдС ЦЕА4001 (стандард који је развијен у Немачкој), НФПА 13 (стандард који је развијен у САД).

Прорачун сваке инсталације почиње одређивањем класе пожарне опасности којој припада дати објекат - простор који се штити. Класе пожарне опасности према ВдС ЦЕА4001 или ЕН 12845, су следеће:

- LH (Light Hazard) - штићена подручја са малим пожарним оптерећењем и малом запаљивошћу материјала.

- ОН (Ordinary Hazard) - штићена подручја са средњим пожарним оптерећењем и средњом запаљивошћу материјала. Деле се у подгрупе ОН1, $\mathrm{OH} 2, \mathrm{OH} 3$ и $\mathrm{OH} 4$.

- HНP (High Hazard Proces) - штићена подручја у области производње са великим пожарним оптерећењем и великом запаљивошћу материјала. Деле се у подгрупе НHР1, НHР2, ННР3, ННР4.

- HHS (High Hazard Storage) - штићена подручја са складиштењем материјала и роба. Деле се на подгрупе HHS I до HHS IV.

\section{7. ТЕХНИЧКИ УСЛОВИ}

Основни прорачун за потребну количину воде, као и конструктивно функционални захтеви базирају се на прописима СРПС ЕН 12845:12.

Прорачун сваке инсталације почиње одређивањем класе пожарне опасности којој припада дати објекат простор који се штити.

Из табеле А.2 Анекса А стандарда, за подземну паркинг гаражу, одређује се средња класа опасности $\mathrm{OH}$, подгрупа - ОН2.

Пројектна количина воде (висина поливања) и површина дејства

Из табеле 3 стандарда, за класу опасности ОН2 одређује се:

- Минимална брзина додтока воде: $5 \mathrm{~mm} / \mathrm{min}$

- површина дејства за мокри систем: $144 \mathrm{~m}^{2}$

Минимални притисак истицања на млазницама

Минимални притисак истицања на млазницама у хидраулички најнеповољнијој ситуацији, за класу опасности ОН, према стандарду је 0,35 бар.

Максимална површина дејства по млазници и максимално растојање између млазница

Из табеле 19 стандарда, за класу опасности ОН одређује се:

- максимална површина дејства по једној млазници: $12 \mathrm{~m} 2$

- максимално растојање између две млазнице: $4 \mathrm{~m}$

Време деловања инсталације

Минимално време деловања инсталације, за класу опасности ОН, према стандарду, је 60 минута.

Коефицијент К млазнице

Номинални коефицијент $\mathrm{K}$ млазница, за класу опасности ОН, према стандарду (Табела 37), је 80.

\section{1 Хидраулички прорачун}

Карактеристике потребног протока и притиска на вентилу и пумпи дате су у табели. Q=981.52 1/min, $\mathrm{P}=2.228$ bar

На основу прорачунатих минималних карактеристика за спринклер пумпу у пумпној станици:

- проток $\mathrm{Q}=981.52$ 1/min 
- напор $\mathrm{H}=24 \mathrm{~m}$

Одабрана је спринклер пумпа произвођача grundfos, тип NK100-400/334, следећих карактеристика у радној тачки:

$$
\begin{aligned}
& \text { - проток } \mathrm{Q}=13901 / \mathrm{min} \\
& \text { - напор } \mathrm{H}=38.5 \mathrm{~m} \\
& \text { - снага електро мотора } \mathrm{P}=21.38 \mathrm{\kappa W}
\end{aligned}
$$

\begin{tabular}{|c|c|c|c|c|c|c|c|c|c|}
\hline \multirow{2}{*}{$a$} & \multicolumn{2}{|l|}{80} & \multirow{2}{*}{\begin{tabular}{|l|}
50.75 \\
50.75 \\
\end{tabular}} & \multirow[b]{2}{*}{ K 0.77} & \multicolumn{2}{|l|}{3.73} & \multirow[b]{2}{*}{0} & \multicolumn{2}{|l|}{0.634} \\
\hline & DN25 & 26.6 & & & 0.77 & 2.96 & & 0.052 & 0 \\
\hline $\mathrm{b}$ & \multicolumn{2}{|l|}{80} & 66.26 & \multirow[b]{2}{*}{ T 1.50} & \multicolumn{2}{|l|}{4.44} & & \multicolumn{2}{|l|}{0.686} \\
\hline$b-c$ & DN25 & 26.6 & 117.01 & & 1.5 & 2.96 & 0 & 0.294 & 0 \\
\hline$c$ & \multicolumn{2}{|l|}{80} & 79.23 & \multirow[b]{2}{*}{ T 2.90} & \multicolumn{2}{|l|}{3.37} & & \multicolumn{2}{|l|}{0.981} \\
\hline$c-1$ & DN32 & 35 & 196.24 & & 2.9 & 1.48 & 0 & 0.151 & 0 \\
\hline 1 & \multicolumn{2}{|c|}{298.56} & 392.48 & & \multicolumn{2}{|l|}{8.05} & & \multicolumn{2}{|l|}{1.132} \\
\hline $1-2$ & DN65 & 62.7 & 392.8 & $\mathrm{P}, \mathrm{T} 4.80$ & 4.8 & 3.25 & 0 & 0.189 & 0 \\
\hline 2 & & & 785.28 & \multirow[b]{2}{*}{ T 3.80} & \multicolumn{2}{|l|}{7.05} & & \multicolumn{2}{|l|}{1.315} \\
\hline $2-3$ & DN65 & 62.7 & 196.24 & & 3.8 & 3.25 & 0 & 0.243 & 0 \\
\hline 3 & & & 981.52 & \multirow[b]{2}{*}{ P 1.0} & \multicolumn{2}{|l|}{14} & & \multicolumn{2}{|l|}{1.558} \\
\hline $3-4$ & DN80 & 77.9 & 981.52 & & 1 & 13 & 0 & 0.253 & 0 \\
\hline 4 & & & 981.52 & \multirow{2}{*}{$P, K, T$ 10. } & \multicolumn{2}{|l|}{42.45} & & \multicolumn{2}{|l|}{1.811} \\
\hline $4-5$ & DN100 & 102.3 & 981.52 & & 410.4 & 32.45 & 0 & 0.204 & 0 \\
\hline 5 & & & 981.52 & & \multicolumn{2}{|l|}{67.25} & & \multicolumn{2}{|l|}{2.015} \\
\hline \multirow[t]{2}{*}{ 18-СВ-П } & DN100 & 102.3 & 981.52 & \multirow{2}{*}{ УК 56.82} & 56.82 & 10.43 & 0 & \multirow{2}{*}{\multicolumn{2}{|c|}{\begin{tabular}{|l|}
0.323 \\
2.338
\end{tabular}}} \\
\hline & & & 981.52 & & & & & & \\
\hline
\end{tabular}

Табела 1. Пад притиска кроз цевовод за избор пумпе

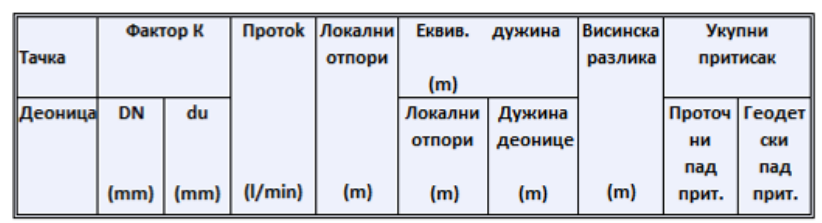

\section{8. ЗАКЉУЧАК}

Подземне гараже су специфични објекти које због свог положаја, намене, вентилације и других фактора представљају изазов за све који се баве заштитом од пожара, а посебно за припаднике ватрогасних јединица. Узроци пожара у оваквим објектима су углавном на возилима, због неисправности или евентуалних радова на истим. Због присуства запаљивих материјала и материја које се налазе у возилима, евентуални пожари на возилима у подземним гаражама би се веома лако и брзо ширили, а постојала би и опасност од могућих експлозија.

Циљ и сврха уградње овакве инсталације у објекат јесте да са једне стране држи евентуални пожар под надзором и контролом, тј. да спречи његово даље ширење, чиме би се добило на времену евакуације људи из угроженог подручја, а друга важна карактеристика овог система је и спречавање прекомерног загревања конструкције објекта ради задржавања интегритета исте, постројења, инсталација и сличног у току самог пожара.
Веома је важно напоменути да се постројење мора уредно одржавати како би се осигурало да, у случају потребе, функционише. Овај задатак може се лако превидети или недовољно уважити. Ако се то догоди тада, то значи опасност по живот људи који се налази и борави у објекту, као и ризик од значајних финансијских трошкова.

\section{9. ЛИТЕРАТУРА}

[1] Инсталације за гашење пожара; З.Секуловић, М.Дамановић, М.Богнер; ЕТА, Београд 2014

[2] Превентивна заштита од пожара; 3.Секуловић, М.Дамановић, М.Богнер; ЕТА, Београд 2012.

[3] Закон о заштити од пожара („Службени гласник PC“, број 111/2009; 20/2015, 87/2018)

[4] Пројектовање противпожарне заштите; В. Бујандрић, Н.Бујандрић; Ведеко, Београд 1996.

[5] Правилник о техничким нормативима за заштиту гаража за путничке аутомобиле од пожара и експлозија („Сл.Лист Србије и Црне Горе“, бр. $31 / 2005)$

\section{Кратка биографија:}

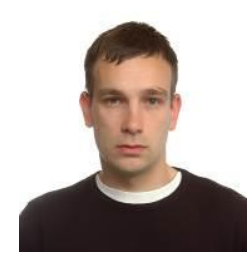

Ненад Драгин рођен је у Новом Саду 1987. године. Факултет техничких наука у Новом Саду, одсек инжењерство заштите животне средине, завршава 2013. год.

На Факултету техничких наука, у Новом Саду, школске 2018/2019. уписује мастер академске студије: Управљање ризиком од катастрофалних догађаја и пожара. Мастер рад из научне области Инжењерство управљања ризиком од катастрофалних догађаја и пожара брани 2020. године. 